\title{
Trace Metals and Volatile Aromatic Hydrocarbon Content of Ukpeliede-I Oil Spillage Site, Niger Delta, Nigeria
}

\author{
OSUJI, L C; *ACHUGASIM, O*
}

\author{
Department of Pure and Industrial Chemistry, \\ University of Port Harcourt, PMB 532, \\ Port Harcourt, Nigeria. E-mail: dawnang2001@yahoo.com
}

\begin{abstract}
S: The composition and distribution of the volatile aromatic components: Benzene, Toluene, Ethylbenzene, Xylene (BTEX) and the variations in the concentration of the trace metals within the sampling interval of two months and five months were studied in an oil impacted soil at Ukpeliede in the Niger Delta area, Nigeria. This was done with a view to assessing the level of attenuation of this particular group of crude hydrocarbons and the changes /effects of some trace metals in the impacted soils. The aromatic hydrocarbon levels were all above the target level of $0.05 \mathrm{mg} / \mathrm{kg}$ after two months post impact period. There was a complete disappearance of the BTEX after the second sampling interval of five months, paralleling a marked reduction of about $71 \%$ in the concentration of zinc within the same sampling period suggesting a common attenuation process or conditions.@ JASEM
\end{abstract}

Nigeria has had its fair share of crude oil pollution. This problem is encountered almost entirely in the Niger Delta area in the southern part of the country. The spate of crude oil spillage in this region has increased geometrically with time. For instance, an average of 122 spills per year was reported between 1970 and 1982 and an average of 1080 spills per year between 2000 and 2004. Nearly all of Nigerian crude is produced from this region that is dotted with over 210 oil fields, 160 flow station and cris-crossed by more than $12000 \mathrm{~km}$ of old flow lines .(Achugasim,2005). Crude oil is a complex mixture of tens of thousands of hydrocarbons and a significant amount of non hydrocarbons. A good knowledge of this hydrocarbon and non hydrocarbon contents and their behaviour when discharged on shore is very useful in the decontamination and effective management of the affected environment. (Osuji and Achugasim, 2007). An important group of the hydrocarbon content of crude oil is the Benzene Toluene Ethylbenzene and Xylene (BTEX), loosely called aromatic hydrocarbons in the oil industry to differentiate them from the polycyclic aromatic hydrocarbons (PAH) since each behaves differently in any environmental matrix. The BTEX form a group of aromatic hydrocarbons that behave alike in the soil. They have been found to degrade easily by microbes compared to the PAHs. (Wang et al, 1994). The trace metals form a very important part of the non-hydrocarbon component of crude oil. They are described as metals occurring at $1000 \mathrm{mg} / \mathrm{kg}$ or less in the environmental matrix under study. The heavy (density $>5 \mathrm{~g} / \mathrm{cm}^{3}$ ) and light (density $<$ $5 \mathrm{~g} / \mathrm{cm}^{3}$ ) trace metals are all found in crude oil. Those usually available include in crude include $\mathrm{Cd}, \mathrm{Cr}, \mathrm{Cu}, \mathrm{Fe}$, $\mathrm{Hg}, \mathrm{Ni}, \mathrm{V}, \mathrm{Pb}, \mathrm{As}, \mathrm{Zn}, \mathrm{Co}, \mathrm{Mn}, \mathrm{Pt}, \mathrm{Ag}$, and Au. They are introduced into crude through many processes such as the disintegration of natural organometalic plant metabolites eg chrolophyll. Some of these trace metals are hazardous while others are not. A number of them are essential at low concentration but becomes deleterious at high concentrations. (Hudgson 1954; Stanislav, 2004). In this study, we have undertaken to study the distribution of BTEX and some trace metals two months and five months after an incidence of oil spillage at Ukpeliede-1 oil spillage site in the Niger Delta Nigeria.

\section{MATERIALS AND METHODS}

Field reconnaissance and sampling: The goal of the field reconnaissance survey was to make an eye assessment of the extent of pollution on site and to delimit the epicentre of the crude oil spillage. Sampling was subsequently carried out by mapping out plots on the spill site using the grid system. One hundred of such grid plots measuring 20 x 20m were mapped out. Thirty three grid plots $(30 \%)$ were randomly selected and soil samples were taken from three replicate quadrates at depths of $0-15 \mathrm{~cm}$. The collected soil samples were packaged, labelled and taken to the laboratory for analyses.

Study site: The study area is an oil spillage site located in Ukpeliede in Ahoada community within an integral part of the humid tropical rain forest in the Niger Delta basin of Nigeria (Fig.1). The spillage was due to pipe line leakage. The site is an entirely dry land devoid of significant water bodies.

Oil Extraction and determination of BTEX and Trace Metals: For the gas chromatographic (GC) determination of BTEX, $5 \mathrm{~g}$ of homogenized soil samples were weighed and transferred into dry beakers. The weighed samples were extracted with $10 \mathrm{ml}$ hexane. The extracts were centrifuged and passed thru a filter paper to ensure complete removal of sand particles. The hydrocarbon / hexane mixture was injected into a Varian model 3400 gas chromatograph with the following operating conditions: flowrate $\left(\mathrm{H}_{2}: 30 \mathrm{ml} / \mathrm{min}\right.$ and $\left.\mathrm{N}_{2}: 30 \mathrm{ml} / \mathrm{min}\right)$; injection temperature of $250^{\circ} \mathrm{C}$; detector temperature of $320^{\circ} \mathrm{C}$; recorder voltage of $1 \mathrm{mV}$; and chart speed of of $1 \mathrm{~cm} / \mathrm{min}$. For interpretation of results, the GC recorder was interfaced with a Hewlett Packard (hp) computer (62070 AA software, Kayakx A PIT/350 w/48 mega bytes CD ROM). The chromatograms were quantified with respect to internal standards. In the determination of the trace metals, $10 \mathrm{~g}$ of homogenized soil samples were weighed, transferred into a beaker and digested with nitric acid in a fume chamber. The digested samples were analysed using Atomic Absorption Spectrophotometer (AAS) as described by Osuji and Onojake, (2004). 


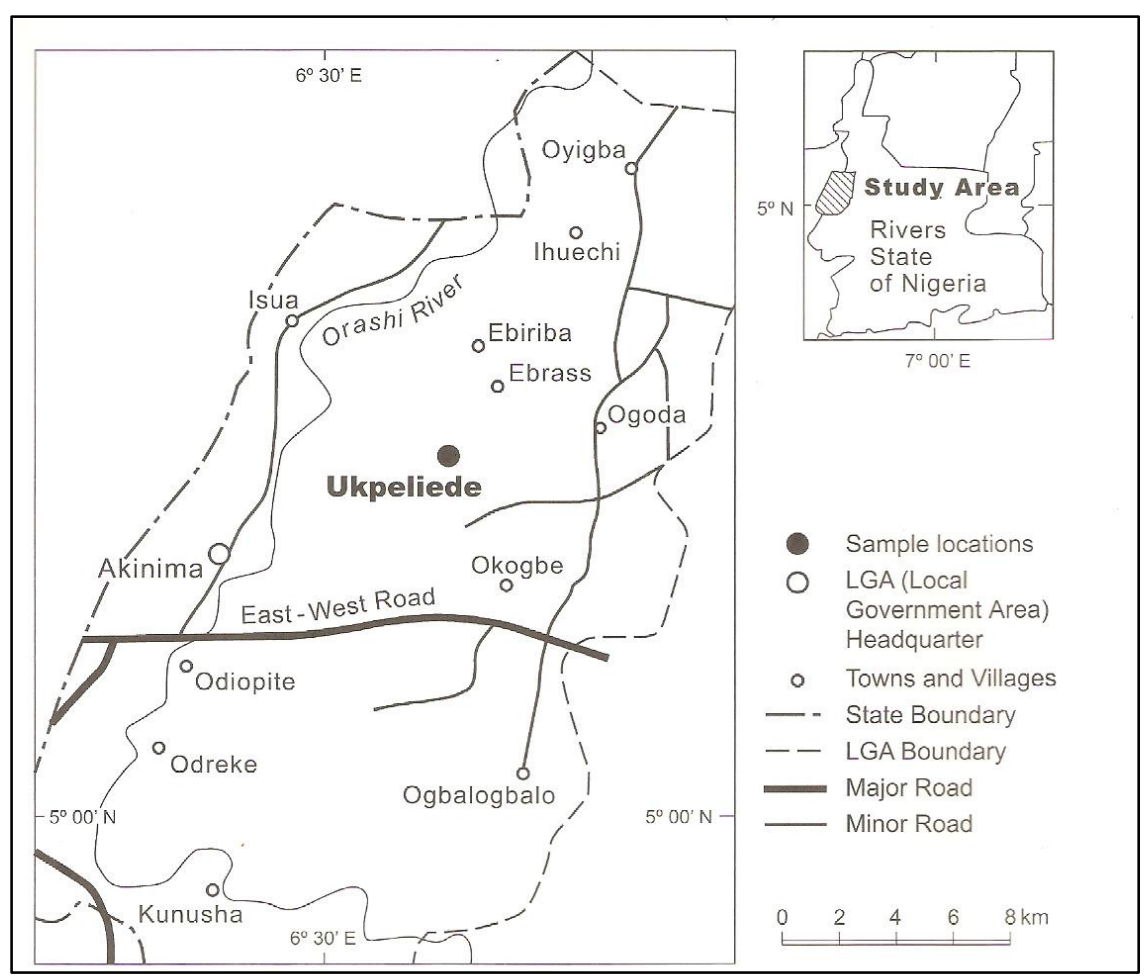

Fig 1. A map of the study area showing the sample site

\section{RESULTS AND DISCUSSION}

The fingerprints of the aromatic components of the spilled oil from the soil samples are presented in tables 1 and figure 2. The primary components of aromatic hydrocarbons are the benzene, toluene, ethylbenzene and xylene (BTEX).

Table 1. TABLE 1: Fingerprints of the aromatic (BTEX) components of the spilt oil two months and five months after spillage. $(\mathrm{BDL}=$ below detectable limit. Detectable limit $=1 \times 10^{-6}$ )

\begin{tabular}{|l|l|l|}
\hline Compound & $\begin{array}{l}\text { 2 months after } \\
\text { spill } \mathbf{( m g / k g})\end{array}$ & $\begin{array}{c}\text { 5 months after } \\
\text { spill } \mathbf{( m g / k g )}\end{array}$ \\
\hline Benzene & $73.21 \pm 14.0$ & BDL \\
\hline Chloro benzene & $9.79 \pm 2.1$ & BDL \\
\hline 1,2 Dichlorobenzene & $20.50 \pm 2.4$ & BDL \\
\hline 1,3 Dichlorobenzene & $37.73 \pm 2.7$ & BDL \\
\hline 1,4 Dichlorobenzene & $4.86 \pm 0.8$ & BDL \\
\hline Ethyl benzene & $7.04 \pm 1.0$ & BDL \\
\hline Toluene & $19.2 \pm 12.5$ & BDL \\
\hline M,p-xylene & $19.69 \pm 3.5$ & BDL \\
\hline o-xylene & $2.04 \pm 1.1$ & BDL \\
\hline
\end{tabular}

In the soil collected at two months post oil spill impact, the aromatic hydrocarbon levels are all above the target value of $0.05 \mathrm{mg} / \mathrm{kg}$ set for petroleum industries in Nigeria by the department of petroleum resourses (DPR) in 2003. Benzene had the highest value of $73.21 \mathrm{mg} / \mathrm{kg}$ with o-xylene having the lowest value of $2.04 \mathrm{mg} / \mathrm{kg}$, though BTEX is volatile and easily degraded under aerobic conditions. These confirms the sampling time and shows that the spilt oil was still fresh as at the time of the first sampling. This inference is in line with the release time value of 3.6 which falls within the range of 1.5 to 6.0 for recent release of oil to the environment according to Kaplan and Galperon (1996) who calculated release time using the relationship: $\mathrm{Rb}$ $=(\mathrm{B}+\mathrm{T}) /(\mathrm{E} * \mathrm{X})$ where $\mathrm{B}=$ benzene, $\mathrm{T}=$ toluene, $\mathrm{E}=$ ethylbenzene and $\mathrm{X}=\mathrm{xylene}$. BTEX are also prone to photo oxidation: a process whereby the hydrocarbons are oxidized into mainly oxygen products (e.g. organic acids and phenol under the influence of an ultraviolet and visible part of the electromagnetic spectrum. Microbes also enjoy a 'meal' of BTEX after the depletion of the lighter paraffins. These contribute to the fast depletion of BTEX in any environmental matrix. (Hunt, 1996) A complete disappearance of this aromatic hydrocarbon after 5 months of the oil spillage was evident, a proof that BTEX is not a good diagnostic tool in oil spill source identification and correlation. Rapid loss and disappearance of BTEX in a spilled oil was reported by Wang et al (1994).

TABLE 2: Concentration of some trace metals two months and five months after oil spillage. (BDL =below detectable limit. Detectable limit $=1 \times 10^{-3}$ )

\begin{tabular}{|l|l|l|}
\hline $\begin{array}{l}\text { Trace } \\
\text { metals }\end{array}$ & $\begin{array}{l}\text { 2 months after } \\
\text { spill }(\mathbf{m g} / \mathbf{k g})\end{array}$ & $\begin{array}{l}\text { 5 months after } \\
\text { spill }(\mathbf{m g} / \mathbf{k g})\end{array}$ \\
\hline Nickel & $0.508 \pm 0.07$ & $0.527 \pm 0.19$ \\
\hline Chromium & $1.984 \pm 0.14$ & $2.156 \pm 0.19$ \\
\hline Zinc & $9.946 \pm 0.98$ & $2.862 \pm 0.376$ \\
\hline Vanadium & BDL & BDL \\
\hline Arsenic & $0.601 \pm 0.12$ & $0.560 \pm 0.15$ \\
\hline Cobalt & $0.471 \pm 0.13$ & $0.501 \pm 0.210$ \\
\hline Iron & $752.36 \pm 50.98$ & $701.70 \pm 40.16$ \\
\hline Lead & BDL & BDL \\
\hline
\end{tabular}




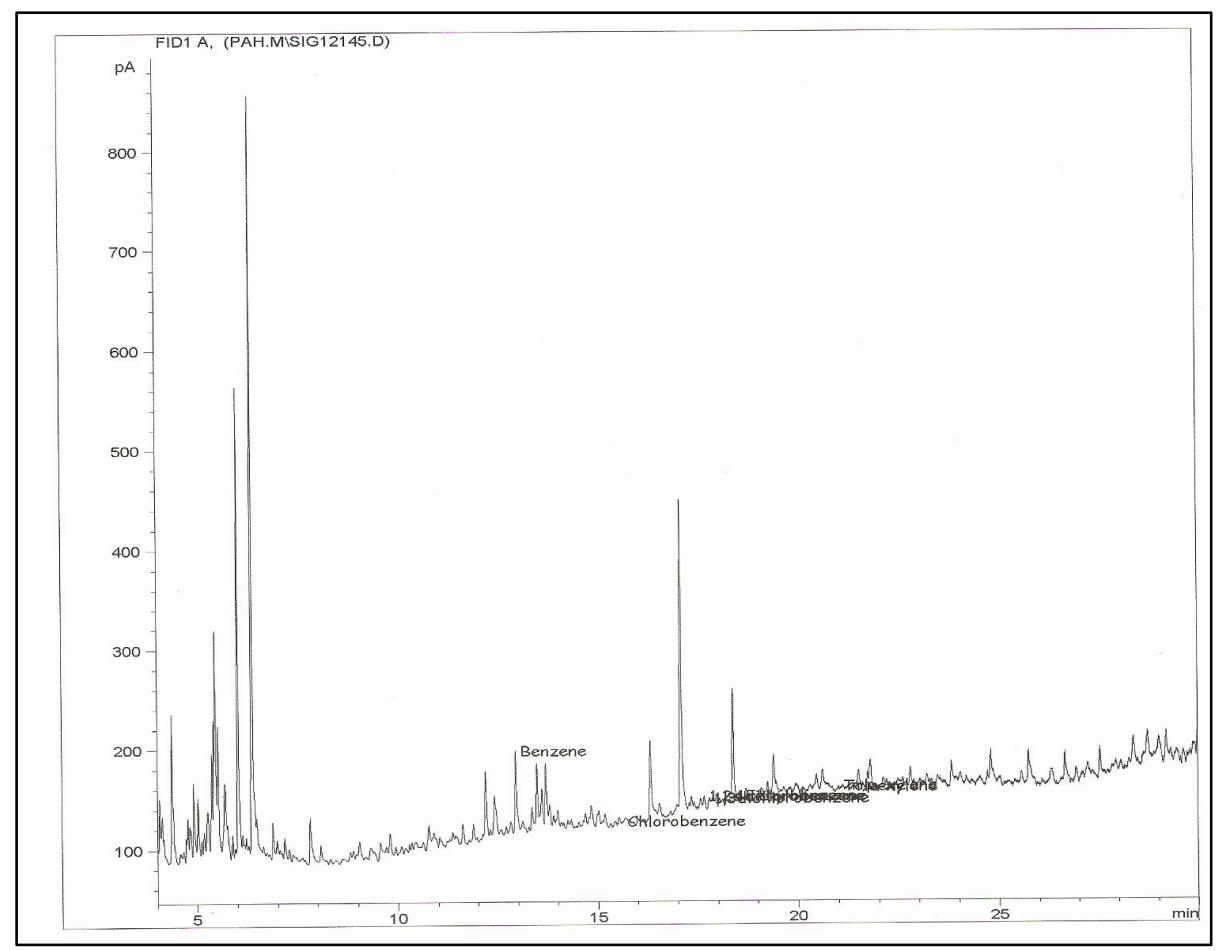

Fig 2. A chromatogram showing the distribution of BTEX in the impacted area

The concentration of some trace metals from the oil polluted site is presented in table 2 . The results show a high concentration of Zinc in the first sampling period which was drastically reduced in the second from $9.946 \pm 0.98 \mathrm{mg} / \mathrm{kg}$ to $2.862 \pm 0.38 \mathrm{mg} / \mathrm{kg}$. a decrease of more than $70 \%$. This suggests that degradation of petroleum hydrocarbon may have occasioned the significant reduction in the concentration of Zinc or vice versa. The concentration of Chromium varied though not significantly and the variation of nickel was not statistically significant. These are all far below the compliance /intervention limit for petroleum industries in Nigeria. The concentration of Vanadium and Lead was so low that they were below the detection limit of the instrument used. This is in agreement with the results obtained by Chinda (2004). Although oils generally have higher concentration of Vanadium than Nickel (Hunt, 1996), Osuji and Onojake (2004) reported higher concentration of of Nickel compared with Vanadium in spilled oils from Niger Delta. This implies a low Vanadium/ Nickel ratio which tends to zero indicating maturation changes in the oil. This low ratio could act as useful fingerprint in future oil correlations. Nickel, Vanadium and Chromium are toxic, so their low lvels is good for the impacted environment. This may be due to the spilled oil being low in these metals or that the remediation process has contributed positively. The site was highly polluted in terms of its Iron content of 752$36 \pm 50.98 \mathrm{mg} / \mathrm{kg}$ and $701.70 \pm 40.16$ respectively for the two months and five months post impact period. This was rather high as it was above the $100 \mathrm{mg} / \mathrm{kg}$ compliance/intervention limit set for petroleum industries in Nigeria. Punanova and Satranova (1993) ranked oils according to their metal contents. In their ranking, the spilled oil at Ukpeliede I is type II given its iron concentration that is higher than that of any other metal

Conclusion: Fingerprints of the Ukpeliede-I oil spill showed a high level of benzene with low level of o-xylene in the first sampling period of two months and a complete disappearance of the aromatic components (BTEX) of the spilt oil after 5 months of the oil spillage, thus BTEX may not be a good tool for oil source identification in crude oil forensics. There was a drastic reduction in the concentration of Zinc between the second and fifth months of the oil spillage which paralleled the disappearance of BTEX. This an indication that processes that that leads to the attenuation of the light end hydrocarbons and BTEX in crude oils may also lead to the degradation of the Zinc content. There was a higherthan normal concentration of Iron in the spilled oil as Vanadium,Lead and Nickel did not get to pollution levels.

\section{REFERENCES}

Chinda, A C (2004). Distribution of hydrocarbon and heavy metals in sediments and a crustacean (shrimps penans notalis) from the Bonny/New Calabar river estuary, Niger Delta. Ageam-Ragee 9: 1-8.

Hudson, G W (1954). Vanadium, Nickel and Iron trace metals in crude oils of western Canada. AAPG Bullet. .38:2537-2554.

Hunt, J M (1996). Petroleum geochemistry and geology. $2^{\text {nd }}$ ed. Freedman and company. New York.

Kaplan, I R; Galperon, Y (1996). How to recorgnize a hydrocarbon fuel in the environment and estimate its 
age of release.In J.J Bois II and B.J. Luther(eds). Groundwater and soil contamination. Technical preparation and litigation.N.York

Osuji, L C (2002). Some Environmental harzards of oil pollution in Niger Delta, Nigeria. Afric. J. Interdisc. Stud. 3:(1) 11-12.

Osuji, L C; Onojake, C M (2004). Trace heavy metals in crude oil: A case study of Ebocha- 8 oil spill polluted site in Niger Delta Nigeria. Chem.Biodiv.1:17081715.

Osuji, L C; Achugasim, O (2007). Environmental Degradation of Polluting aromatic and aliphatic hydrocarbons: A case study. Chem.Biodiv. 4:424430 .
Ozioma, A (2005). Analysis of soils from Ukpeliede oil spill site, River state, Nigeria. M.Sc. Thesis, University Of Port Harcourt, Nigeria.

Punanova, S A; Stanislav, T A (1993). Metal contents of crude oils from the Afghan-Tadzihik depression. Petro. Chem.33 496-504.

Stanislav, P (2004). Environmental impacts of offshore and gas industry.New York U.S.A.

Wang, Z; Fingas, M; Sergy Z (1994). Study of the 22year oil arrow oil samples using biomarker compounds by GC.MS. Environ. Sc.Technol. 28:1733-17 